Our own experience of selective visceral arteriography is at present limited. Further experience will be required to define its place in the investigation of gastrointestinal haemorrhage. In time more precise criteria of abnormalities on the arteriogram will be formulated. There is little doubt that selective visceral arteriography should be used more widely than is the practice in this country at present.

We wish to thank Dr. D. H. MacKenzie for the photomicrograph and the department of medical illustration, Westminster Hospital, for the other photographs. We are grateful to Mr. A. G. Rutter for allowing us to report Case 1, and to Mr. E. S. Lee and Professor M. D. Milne for allowing us to report Case 2. Case 2 was presented at the Clinical Section of the Royal Society of Medicine on 9 February 1968, and is reported by kind permission of the President of the Section.

\section{REFERENCES}

Baum, S., Nusbaum, M., Blakemore, W. S., and Finkelstein, A. K. (1965). Surgery, 58, 797.

Baum, S., Nusbaum, M., Clearfield, H. R., Kuroda, K., and Tumen, H. J. (1967). Arch. intern. Med., 119, 16.

Berkowitz, D. (1963). Amer. ₹ Gastroent., 40, 372.

Birke, G., and Engstedt, L. (1956). Gastroenterologia (Basel), 85, 97.

Bongiovi, J. J., and Duffy, J. L. (1967). Arch. Surg., 95, 93.

Gentry, R W, Dockerty, M. B. and Clagett, O. T. (1949). Int. Abstr. Surg., 88, 281.

Jones, F., A., Read, A. E., and Stubbe, J. L. (1959). Brit. med. F., 1, 1138 .

Nebesar, R. A., Pollard, J. J., Edmunds, L. H., and McKhann, C. F. (1964). Amer. F. Roentgenol., 92, 1100.

Rctzlaff, J. A., Hagedorn, A. B., and Bartholomew, L. G. (1961). J. Amer. med. Ass., $177,104$.

Reuter, S. R., and Bookstein, J. J. (1968). Gastroenterology, 54, 876.

Rissier, H. L. (1960). Gastroenterologia (Basel), 93, 357.

Rutter, A. G. (1956). Lancet, 2, 1077.

Shepherd, J. (1953). Brit. F. Surg. 40, 409.

Shepherd, A. (195). Brit.

Ström, B. G., and Winberg, T. (1962). Acta Radiol. (Stockh.), 57, 401.

\title{
Function of Cadaver Renal Homografts in Relation to Age of Donor, Cause of Death, and Ischaemia Time
}

\author{
H. J. O. WHITE,* M.CHIR., F.R.C.S. ; D. B. EVANS, † M.B., M.R.C.P. ; R. Y. CALNE, $\ddagger$ M.S., F.R.C.S.
}

Brit. m.ed. F., 1968, 4, 739-740

Cummary : Twenty-six renal grafts four months or more $\checkmark$ after transplantation have been shown to function satisfactorily when the donor's age has varied from 10 to 64 years and the period of warm ischaemia has been between 26 and 133 minutes. It is suggested that a more lenient view be adopted with respect to the age of the donor, but that a warm ischaemia time of two hours should not be exceeded.

\section{Introduction}

The ideal donor (Nolan, 1967) of a cadaveric kidney for transplantation might be considered to be a person under the age of 45 years who has remained normotensive until a short time before death, who is free of transmissible infection and malignancy, and who dies in hospital after observation for a number of hours, during which time blood group and tissue type may be determined and urinary function assessed. The donor kidneys must then be removed within minutes and certainly within an hour of death. Such an ideal donor situation is not infrequent in the United States, where road traffic accidents and gunshot wounds are common and so provide adequate donors of this ideal type for the needs of renal transplantation. In Great Britain such ideal donors are the exception rather than the rule, and in this reported series (Calne et al., 1968) possibly only three donors out of 36 would have fulfilled all these criteria.

It is the purpose of this paper to study the function of the cadaveric kidneys with respect to the age of the donor, the cause of the donor's death, and the length of ischaemia time, in the hope that a case may be made for using what might be

\footnotetext{
- Honorary Senior Surgical Registrar, United Cambridge Hospitals. At present Lecturer in Surgery, Bristol University ; Consultant Surgeon, Southmead Hospital, Bristol.

† Senior Medical Registrar, Renal Unit, Addenbrooke's Hospital, Cambridge.

† Professor of Surgery, University of Cambridge.
}

termed "second-class donors" in order to satisfy the needs of renal transplantation in this country at the present time. It is admitted that the use of such donor kidneys is often followed by a period of acute tubular necrosis in the transplanted kidney, and this may make the early diagnosis of a threatened rejection extremely difficult.

\section{Materials and Methods}

Between 15 March 1966 and 1 April 196845 patients received 50 cadaveric renal transplants in Cambridge (Calne et al., 1968). Of these 45 recipients 13 have died and five further transplants have had to be removed for reasons of rejection, secondary haemorrhage, or venous thrombosis, all of which occurred within a four-month period following transplantation. It was therefore decided to assess the function of these cadaveric grafts at the end of this initial four-month period. This allows 26 grafts to be studied. The remaining six functioning grafts have been transplanted too recently for assessment at this period of time, three of these being second transplants and three first transplants. These 26 grafts have been obtained from 24 donors, 6 of whom died from cerebrovascular accidents, 2 from cerebral tumour, 8 from myocardial infarction, and 7 from road traffic accidents-2 kidneys being used on two occasions from this source-and a further graft was obtained from a patient dying of a pulmonary embolus.

\section{Results}

Fig. 1 shows the age of the donor plotted against the serum creatinine at the end of the four-month period following transplantation; it will be seen that the age of the donor really has no effect on the function of the graft at the end of this time, there being a random distribution of function irrespective of age. Table I shows the average serum creatinine at four months for each decade of the donor's age. Though the average for the over-60s is slightly higher at $1.9 \mathrm{mg} . / 100 \mathrm{ml}$., it is accounted for by a high serum creatinine $(3 \mathrm{mg} . / 100 \mathrm{ml}$.) in one patient. 


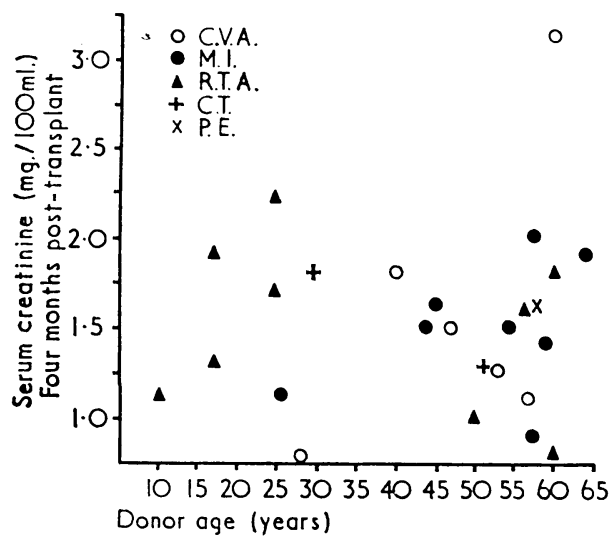

FIG. 1

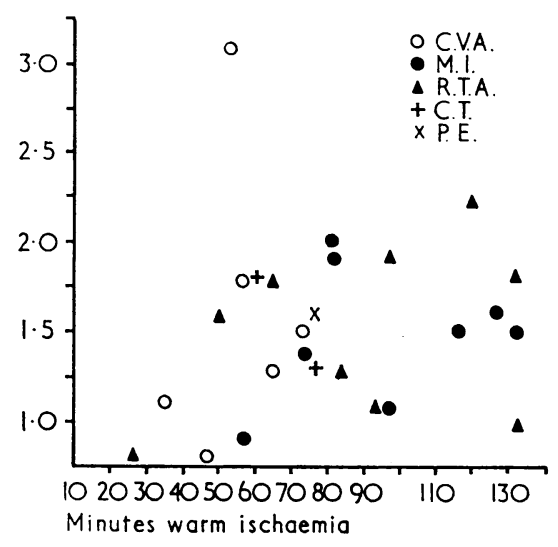

FIG. 2

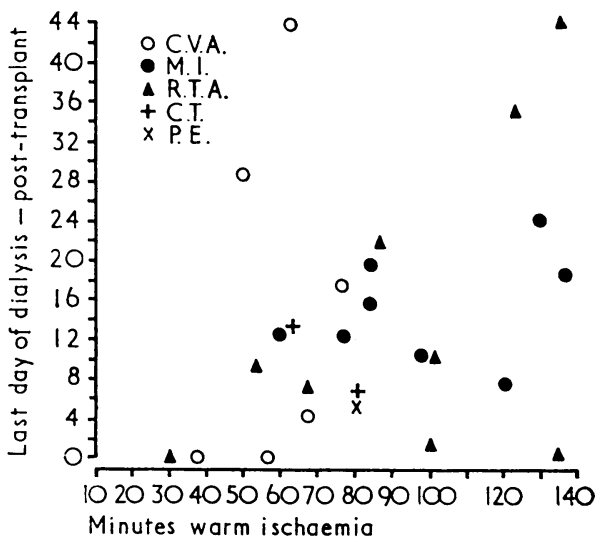

FIG. 3

\begin{tabular}{|c|c|c|c|c|}
\hline \multicolumn{4}{|c|}{ Donor Ages } & $\begin{array}{c}\text { Mean Serum Creatinine } \\
\text { (mg./100 ml.) } \\
4 \text { Months Post-transplant }\end{array}$ \\
\hline $\begin{array}{l}10-19 \text { years ( } 3 \text { donors) } \\
20-29 \text { years (4 donors) } \\
30-39 \text { years (1 donor) } \\
40-49 \text { years (5 donors) } \\
50-59 \text { years (9 donors) } \\
60-69 \text { years ( } 4 \text { donors) }\end{array}$ & $\begin{array}{l}\because \\
\because \\
\because \\
\cdots\end{array}$ & $\begin{array}{l}\because \\
\because \\
\cdots\end{array}$ & $\begin{array}{l}\cdots \\
\because \\
\cdots \\
\cdots \\
\cdots\end{array}$ & $\begin{array}{l}1.43(1.1-1.9) \\
1.45(0.8-2.2) \\
1.8 \\
1.68(1.5-1.8) \\
1.41(0.9-2.0) \\
1.9(0.8-3.1)\end{array}$ \\
\hline
\end{tabular}

Fig. 2 plots the serum creatinine at four months against the period of warm ischaemia ; that is, the time from the death of the donor to removal of the organ, with the addition of the time taken for the vascular anastomoses. It does not include the cold ischaemia time ; that is, the time following the removal of the kidney when it is placed in ice until it is again removed from ice before vascular anastomosis. In Fig. 2 there is no correlation between the period of warm ischaemia and the function at four months, and in only one case does the serum creatinine exceed $2 \mathrm{mg} . / 100 \mathrm{ml}$. In Table II the mean serum creatinine at four months after transplantation is calculated with respect to the half-hour periods of warm ischaemia up to two and a half hours, and the average creatinine in the longest period, over 120 minutes, is still only $1.45 \mathrm{mg} . / 100 \mathrm{ml}$. in four patients.

\begin{tabular}{|c|c|c|c|c|c|}
\hline \multicolumn{5}{|c|}{ TABLB II } & \multirow{2}{*}{$\begin{array}{c}\begin{array}{c}\text { Mean Serum Creatinine } \\
\text { (mg./100 ml.) }\end{array} \\
4 \text { Months Post-transplant } \\
0.8 \text { (1 patient) }\end{array}$} \\
\hline \multicolumn{5}{|c|}{ Warm Ischaemia Time } & \\
\hline $\begin{array}{l}\text { Less than } 30 \mathrm{~min} . \\
30-60 \text { min. } \\
61-90 \text { min. } \\
91-120 \text { min. } \\
121-133 \text { min. }\end{array}$ & $\begin{array}{l}\cdots \\
\cdots \\
\cdots\end{array}$ & $\begin{array}{l}\cdots \\
\because \\
\cdots \\
\cdots\end{array}$ & $\begin{array}{l}\cdots \\
\cdots \\
\cdots\end{array}$ & $\begin{array}{l}\ldots \\
\because \\
\cdots \\
\cdots\end{array}$ & $\begin{array}{l}0.8 \text { (1 patient) } \\
1.57(0.8-3.1) \text { (7 patients) } \\
1.59(1.3-2 \cdot 0) \text { ( } 9 \text { patients) } \\
1.56(1.1-2 \cdot 2) \text { (5 patients) } \\
1.45(1.0-1.7) \text { (4 patients) }\end{array}$ \\
\hline
\end{tabular}

In Fig. 3 the number of days after transplantation that dialysis has been required has been plotted against the period of warm ischaemia time. As might be expected, with a few exceptions the longer the period of warm ischaemia the longer postoperative dialysis has been required. In Figs. 1-3 the source of the donor organs is indicated by symbols to show their different origin, whether it be from a donor dying from cerebrovascular disease (C.V.A.), myocardial infarction (M.I.), road traffic accident (R.T.A.), cerebral tumour (C.T.), or pulmonary embolus (P.E.). As might be expected, the majority of the younger donors have died from road traffic accidents; in the older group cerebrovascular and myocardial infarction are commoner.

\section{Discussion}

There is nothing in this series to suggest that even the more elderly donors up to the age of 65 have not proved to be perfectly satisfactory, the mean donor age being 52.8 years (10-64 years) compared with a mean of 40.5 years (10-64 years) in the grafts of patients who have died or whose grafts have been rejected or removed.

The next point to be considered is the effect of a prolonged warm ischaemia time on the ultimate function of a cadaver graft. In kidney transplantation, for which dialysis should always be available, it is possible to support the transplanted patient until such time as function recovers in the graft, unlike the situation in transplantation of unpaired organs. These results show that a prolonged warm ischaemia time has little or no detrimental effect on the ultimate function of the graft. Williams, White, and Hume (1967) showed that in cadaver kidneys with acute tubular necrosis following transplantation there was a lower incidence of rejection and an equally good function in the long term. It might be considered that cadaver grafts obtained from patients dying a prolonged hypotensive and anoxic death would be more damaged by ischaemia than those kidneys removed rapidly after sudden death from a road traffic accident, or maybe a myocardial infarction; but this did not seem to be borne out by the results in this series.

\section{REFERENCES}

Calne, R. Y., et al. (1968). Brit. med. F., 2, 404.
Nolan, B. (1967). In Renal Disease, edited by D. A. K. Black, 2nd ed., p. 478. Oxford and Edinburgh.
p.

W. 478. Oxford and Edinburgh. tion, $5,837$. 